\title{
Optimization of Ethanol Production from Palmyra Sap by Zymomonas mobilis Using Response Surface Methodology
}

\author{
RUTH CHRISNASARI ${ }^{1 *}$, AGUSTIN KRISNA WARDANI ${ }^{2}$, AND UNTUNG MURDIYATMO² \\ ${ }^{I}$ Departement of Biology, Faculty of Biotechnology, Universitas Surabaya, \\ Jalan Raya Kalirungkut, Surabaya 60292, Indonesia; \\ ${ }^{2}$ Departement of Food Technology, Faculty of Agricultural Technology, Universitas Brawijaya, \\ Jalan Veteran, Malang 65145, Indonesia
}

\begin{abstract}
Ethanol is believed to be one of the best alternatives to replace gasoline, because ethanol is a renewable energy source and environmentally friendly. The present study focuses on the optimization of palmyra sap as a source for ethanol production. Statistical experimental design using Box-Wilson central composite design was used to optimize the quantitative effects of sugar, urea, and inoculum concentration on ethanol production. It was found that palmyra sap could be used as a substrate for ethanol production using Zymomonas mobilis (NRRL B-14234). A maximum ethanol concentration of $58.97 \mathrm{~g} \mathrm{~L}^{-1}$ was obtained after optimizing the parameters of fermentation. The optimum values of sugar, urea, and inoculums concentration were $206.01 \mathrm{~g} \mathrm{~L}^{-1}, 3.16 \mathrm{~g} \mathrm{~L}^{-1}$, and 23.05\% $\left(\mathrm{v} \mathrm{v}^{-1}\right)$, respectively, with ethanol yield of $0.3039 \mathrm{~g} \mathrm{~g}^{-1}$. A high similarity was observed between the predicted and experimental results, which reflected the accuracy and applicability of RSM to optimize the process for ethanol production.
\end{abstract}

Key words: ethanol, palmyra sap, Zymomonas mobilis, response surface methodology

Etanol merupakan sumber energi alternatif yang berpotensi sebagai pengganti bahan bakar minyak karena bersifat terbarukan dan ramah lingkungan. Penelitian ini bertujuan untuk mengoptimasi nira siwalan sebagai substrat untuk produksi etanol. Pengaruh kuantitatif dari konsentrasi gula, urea, dan inokulum pada produksi etanol dioptimasi menggunakan response surface methodology Box-Wilson central composite design. Hasil penelitian menunjukkan nira siwalan dapat dimanfaatkan sebagai substrat untuk produksi etanol menggunakan Zymomonas mobilis (NRRL B-14234). Konsentrasi etanol maksimum yang dapat dicapai adalah $58.97 \mathrm{~g} \mathrm{~L}^{-1}$ dengan pengaturan kondisi fermentasi: kadar gula substrat $206.01 \mathrm{~g} \mathrm{~L}^{-}$ ${ }^{1}$, kadar urea $3.16 \mathrm{~g} \mathrm{~L}^{-1}$, dan kadar inokulum $23.05 \% \mathrm{v} \mathrm{v}^{-1}$. Perolehan etanol yang dihasilkan adalah $0.3039 \mathrm{~g} \mathrm{~g}^{-1}$. Tingginya tingkat kesamaan antara hasil prediksi model dan hasil penelitian aktual merefleksikan akurasi dan kemampuan aplikasi RSM untuk optimasi produksi etanol.

Kata kunci:etanol, nira siwalan, Zymomonas mobilis, response surface methodology

Due to the progressive depletion of energy resources which mostly based on non-renewable fuels, the era of bioenergy started. Ethanol is believed to be one of the best alternative to replace gasoline because ethanol is a renewable energy source and environmentally friendly (Bai et al. 2008). Ethanol can be produced from several different raw materials, such as sugar based (Cazetta et al. 2007; Limtong et al. 2007), starch based (Jamai et al. 2007; Quintero et al. 2007) and lignocelluloses based materials (Rogers, 1997; Taherzadeh and Karimi 2007). Selections of appropriate raw materials are important to reduce production cost and to increase the efficiency of ethanol production (Elisson et al.2001).

Palmyra sap (Borassus flabellifer) is sugar syrup derived from palmyra tree. The syrup is known to have complete nutrition e.g. sugar, protein, nitrogen, minerals, vitamin B complex that impelled the growth of microorganism (Morton 1988). Palmyra sap is an agricultural product abundantly available in Indonesia, especially in Tuban and the northern coastal area of

*Corresponding author, Phone: +62-31-2981399, Fax:+62-31-2981278, E-mail: ruth_c @ubaya.ac.id
Java. Palmyra sap is usually used as raw material for jaggery production and for local consumption of fermented products such as toddy, vinegar and traditional alcoholic beverages (Ristiarini et al. 2001; Barh and Mazumdar 2008; Sarulli 2009). Jayaseelan and Seevaratnam (1986) used this raw material for ethanol and biomass production using Saccharomyces cerevisiae $\mathrm{Y} 18$, but there is no report for optimization of ethanol production from this raw material using the other microorganism.

Zymomonas mobilis, a Gram-negative bacterium, have been attracted attention for fuel ethanol production. It is an osmo- and ethanol-tolerant bacterium and has shown higher specific rates of glucose uptake. It was also shown to produce ethanol at rate more than twice the reported rates for yeasts (Rogers et al. 1982; Rogers et al. 1997; Gunasekaran and Raj, 1999; Jeffries, 2005; Seo et al. 2005) via the Entner-Doudoroff pathway under anaerobic conditions. Z. mobilis may have a greater potential for industrial ethanol production from raw sugar, molasses, sugarcane juice and sugarcane syrup (Gunasekaran et al. 1986; Lee and Huang 2000). Recent process development has demonstrated the 
potential superiority of this organism in other aspects of industrial ethanol production.

To develop a process for maximum production of ethanol, standardization and optimization of fermentation process is crucial. Fermentation process of ethanol needs precise concentration of sugar as carbon source, urea as nitrogen source, and amount of inoculum. Optimization by the classical method using a single dimensional search involving changing one variable while fixing the others at a certain level is laborious and time consuming, especially when the number of variables is large. These drawbacks of single factor optimization process can be eliminated by optimizing all the affecting parameters collectively by Central Composite Design (CCD) using Response Surface Methodology (RSM).

Optimization using RSM is the suitable method for identifying the effect of individual variables and for seeking the optimum conditions for multivariable system efficiently. This method has been successfully applied to optimize fermentation processes (Sunitha et al. 1998; Ambati and Ayyanna 2001; Ratnam 2001; Ratnam et al. 2003; Ratnam et al. 2005; Bandaru et al. 2006). A detailed account of this technique has been outlined (Box et al. 2005). Basically, this optimization process involves three major steps: performing the statistically designed experiments, estimating the coefficient in a mathematical model and predicting the response and checking the adequacy of the model (Ratnam et al. 2005).

In this study, the RSM approach was adopted to locate optimum level of sugar, urea, and inoculum concentration for ethanol fermentation from palmyra sap using Zymomonas mobilis, since these parameters play a key role in the enhancement of ethanol yield. Optimization was done with Box-Wilson RSM CCD. Here, we demonstrated the potential of palmyra sap for ethanol production and probably the first report on use of RSM for optimization ethanol production using palmyra sap.

\section{MATERIALS AND METHODS}

Bacterial Strain. Zymomonas mobilis ZM4 (NRRL B-14234) obtained from ARS Culture Collection National Center for Agricultural Utilization Research, Preoria Il, USA, was used throughout the study.

Growth Medium and Growth Conditions. Z. mobilis was maintained on medium having composition $\left(\mathrm{g} \mathrm{L}^{-1}\right)$ : glucose, 100; yeast extract, $10 ; \mathrm{KH}_{2} \mathrm{PO}_{4}, 1$; $\left(\mathrm{NH}_{4}\right)_{2} \mathrm{SO}_{4}, 1 ; \mathrm{MgSO}_{4} \cdot 7 \mathrm{H}_{2} \mathrm{O}, 0.5$ and the cells were grown at a temperature of $35^{\circ} \mathrm{C}$ and $\mathrm{pH}$ of 5.5.
Production Medium and Fermentation. The fermentation medium was from palmyra sap, which is collected from Tuban, East Java, Indonesia. The fresh palmyra sap was filtered and concentrated by boiling for $\pm 2-3 \mathrm{~h}$ until total sugar concentration $\pm 450 \mathrm{~g} \mathrm{~L}^{-1}$. Fermentation medium was made from dilution of concentrated palmyra sap using several sugar concentration $\left(115.9,150,200,250\right.$, and $\left.284.1 \mathrm{~g} \mathrm{~L}^{-1}\right)$. Several different concentrations of urea $(1.319,2,3,4$, and $4.682 \mathrm{~g} \mathrm{~L}^{-1}$ ) were added. The medium was sterilized and inoculated with several different concentrations of inoculum cultures $(11.59,15,20,25$ and $28.41 \%$ $\left.\mathrm{v} \mathrm{v}^{-1}\right)$. Fermentation was carried out in batch condition using waterbath shaker. Fermentation condition was maintained at $30{ }^{\circ} \mathrm{C}$ with initial $\mathrm{pH} 7$ and incubated for $60 \mathrm{~h}$.

Analytical Methods. The amount of reducing sugar was estimated using DNS method. The total sugar and total nitrogen concentrations were measured using micro Kjeldahl method. The amount of ethanol was estimated by spectroscopy method (megazyme ethanol kit) at $340 \mathrm{~nm}$. Cell concentration was estimated using spectroscopy at $560 \mathrm{~nm}\left(\mathrm{OD}_{560}\right)$ and the number of cell was counted with haemocytometer.

Experimental Design and Optimization. The aim of this study was to find the optimum levels of sugar, urea and inoculum concentrations for ethanol production from palmyra sap using Z. mobilis. Central composite experimental design was used in the optimization of ethanol production. Sugar concentration $\left(X_{1}, \mathrm{~g} \mathrm{~L}^{-1}\right)$, urea $\left(X_{2}, \mathrm{~g} \mathrm{~L}^{-1}\right)$, and inoculum $\left(X_{3}, \% \mathrm{v} \mathrm{v}^{-1}\right)$ were chosen as independent variables and ethanol concentration $\left(Y i, \mathrm{~g} \mathrm{~L}^{-1}\right)$ was used as output variable. For statistical calculations the variables $\mathrm{Xi}$ were coded as $X i$ according to Equation (1).

$$
\mathrm{x}_{\mathrm{i}}=\frac{x i-x i}{\Delta x j}, \quad i=1,2,3, \ldots . . k
$$

where, $x_{i}$ is the dimensionless value of an independent variable, $X i$ is the real value of an independent variable, $x i$; is the real value of the independent variable at the center point and $\Delta x j$ is step change. Table 1 shows independent variable that used in this experimental plan. A $2^{3}$-factorial CCD, with six axial points $(\alpha=\sqrt{3})$ and six replications at the center points $\left(n_{0}=6\right)$ leading to a total number of 20 experiments was employed in Table 2.

The second degree polynomials (Equation (2)) were calculated with the statistical package(Stat-Ease Inc, Minneapolis, MN, USA) to estimate the response of the dependent variable: 
Table 1 Independent variable in the experimental plan

\begin{tabular}{lccccc}
\hline \multirow{1}{*}{ Variable } & \multicolumn{5}{c}{ Coded Level } \\
\cline { 2 - 6 } & $-1,682$ & -1 & 0 & 1 & 1,682 \\
\hline Total Sugar (g/L), & 115.9 & 150 & 200 & 250 & 284.1 \\
$X_{I}$ & 1.318 & 2 & 3 & 4 & 4.682 \\
Urea (g/L), $X_{2}$ & 11.59 & 15 & 20 & 25 & 28.41 \\
$\begin{array}{l}\text { Inoculums (\% } \\
\text { v/v), } X_{3}\end{array}$ & & & & & \\
\hline
\end{tabular}

Table 2 The CCD matrix employed for three independent variables

\begin{tabular}{|c|c|c|c|}
\hline $\begin{array}{c}\text { Experiment } \\
\text { Number }\end{array}$ & $X_{1}$ & $X_{2}$ & $X_{3}$ \\
\hline 1 & -1 & -1 & -1 \\
\hline 2 & 1 & -1 & 1 \\
\hline 3 & -1 & 1 & 1 \\
\hline 4 & 1 & 1 & -1 \\
\hline 5 & 0 & 0 & 0 \\
\hline 6 & 0 & 0 & 0 \\
\hline 7 & -1 & -1 & 1 \\
\hline 8 & 1 & -1 & -1 \\
\hline 9 & -1 & 1 & -1 \\
\hline 10 & 1 & 1 & 1 \\
\hline 11 & 0 & 0 & 0 \\
\hline 12 & 0 & 0 & 0 \\
\hline 13 & -1.682 & 0 & 0 \\
\hline 14 & 1.682 & 0 & 0 \\
\hline 15 & 0 & -1.682 & 0 \\
\hline 16 & 0 & 1.682 & 0 \\
\hline 17 & 0 & 0 & -1.682 \\
\hline 18 & 0 & 0 & 1.682 \\
\hline 19 & 0 & 0 & 0 \\
\hline 20 & 0 & 0 & 0 \\
\hline
\end{tabular}

$$
\begin{gathered}
Y_{i}=b_{0}+b_{1} X_{1}+b_{2} X_{2}+b_{3} X_{3}+b_{11}+b_{22}+b_{33} \\
b_{12} X_{1} X_{2}+b_{23} X_{2} X_{3}+b_{13} X_{1} X_{3}
\end{gathered}
$$

where $Y i$ is the predicted response, $X_{1}, X_{2}, X_{3}$ are independent variables, $b_{0}$, is the offset term, $b_{1}, b_{2}, b_{3}$ are linear effects, $b_{11}, b_{22}, b_{33}$ are squared effects and $b_{12}, b_{23}$, $b_{13}$ are interaction terms.

\section{RESULTS}

RSM is a sequential procedure with an initial objective of leading the experimenter rapidly and efficiently to the general vicinity of the optimum. Since the location of the optimum is unknown prior to running RSM experiments, it makes sense to have a design that provides equal precision of estimation in all directions employed.

The three factors that highly influence the fermentative production are sugar concentration, urea concentration and inoculum concentration. Using CCD, a total number of 20 experiments with different combinations of sugar, urea, inoculum were performed (Tables 1 and 2). The response was taken at the maximum ethanol production which was observed at $60 \mathrm{~h}$. The results were analyzed using the analysis of variance and the estimation model analysis was done using Sequential Model Sum of Squares, Lack of Fit Tests and Model Summary Statistics. Prediction model that might be occur from response surface method were linear, 2FI (two factor interaction), quadratic and cubic. The result showed that suggestion model was Quadratic. The following second order polynomial equation was found to represent the ethanol production adequately:

$$
\begin{aligned}
Y_{i}= & -234.38018+1.90689 X_{1}+32.22936 X_{2}+3.72154 X_{3} \\
& -0.057275 X_{1} X_{2}+0.015335 X_{1} X_{3}+0.51575 X_{2} X_{3} \\
& -4.93427 \times 10^{-3} X_{1}^{2}-5.27344 X_{2}-0.18322 X_{3}^{2}
\end{aligned}
$$

\begin{tabular}{|c|c|c|c|c|c|c|}
\hline Source & Sum of Squares & df & Mean Square & F value & $\begin{array}{c}\text { P value } \\
\text { Prob }>\text { F }\end{array}$ & \\
\hline Block & 4.59 & 2 & 2.30 & & & \\
\hline Model & 3303.77 & 9 & 367.09 & 1325.71 & $<0.0001$ & Significant \\
\hline A-Sugar & 158.16 & 1 & 158.16 & 571.19 & $<0.0001$ & Significant \\
\hline B-Urea & 4.15 & 1 & 4.15 & 14.99 & 0.0047 & Significant \\
\hline C-Inoculums & 346.24 & 1 & 346.24 & 1250.42 & $<0.0001$ & Significant \\
\hline $\mathrm{AB}$ & 65.61 & 1 & 65.61 & 236.94 & $<0.0001$ & Significant \\
\hline $\mathrm{AC}$ & 117.58 & 1 & 117.58 & 424.64 & $<0.0001$ & Significant \\
\hline $\mathrm{BC}$ & 53.20 & 1 & 53.20 & 192.13 & $<0.0001$ & Significant \\
\hline$A^{2}$ & 2191.23 & 1 & 2191.23 & 7913.53 & $<0.0001$ & Significant \\
\hline $\mathrm{B}^{2}$ & 400.45 & 1 & 400.45 & 1446.22 & $<0.0001$ & Significant \\
\hline $\mathrm{C}^{2}$ & 302.12 & 1 & 302.12 & 1091.10 & $<0.0001$ & Significant \\
\hline Residual & 2.22 & 8 & 0.28 & & & \\
\hline Lack of Fit & 1.18 & 5 & 0.24 & 0.69 & 0.6663 & Not significant \\
\hline Pure error & 1.03 & 3 & 0.34 & & & \\
\hline Cor Total & 3310.58 & 19 & & & & \\
\hline Std. Dev. & & 0.53 & \multicolumn{3}{|c|}{ R Squared } & 0.9993 \\
\hline Mean & & 42.77 & \multirow{2}{*}{\multicolumn{3}{|c|}{$\begin{array}{l}\text { Adj R-Squared } \\
\text { Pred R-Squared }\end{array}$}} & 0.9986 \\
\hline C.V. $\%$ & & 1.23 & & & & 0.9944 \\
\hline PRESS & & 18.46 & \multicolumn{3}{|c|}{ Adeq Precision } & 100.278 \\
\hline
\end{tabular}

Table 3 ANOVA for full quadratic model 
Table 4 Experimental and the predicted value of ethanol yield

\begin{tabular}{|c|c|c|c|c|}
\hline \multirow{2}{*}{$\begin{array}{c}\mathrm{X} 1 \\
\text { Sugar }\left(\mathrm{g} \mathrm{L}^{-1}\right)\end{array}$} & \multirow{2}{*}{$\begin{array}{c}\text { X2 } \\
\text { Urea }\left(g^{-1}\right)\end{array}$} & \multirow{2}{*}{$\begin{array}{c}\mathrm{X} 3 \\
\text { Inoculums }\left(\% \mathrm{v} \mathrm{v}^{-1}\right)\end{array}$} & \multicolumn{2}{|c|}{ Ethanol $\left(\mathrm{g} \mathrm{L}^{-1}\right)$} \\
\hline & & & Actual & Predicted \\
\hline 150 & 2 & 15 & 31.92 & 31.39 \\
\hline 250 & 2 & 15 & 36.11 & 36.26 \\
\hline 150 & 4 & 15 & 30.16 & 30.86 \\
\hline 250 & 4 & 15 & 24.48 & 24.27 \\
\hline 150 & 2 & 25 & 28.43 & 28.64 \\
\hline 250 & 2 & 25 & 49.54 & 48.84 \\
\hline 150 & 4 & 25 & 38.57 & 38.42 \\
\hline 250 & 4 & 25 & 46.64 & 47.16 \\
\hline 115.91 & 3 & 20 & 17.45 & 17.30 \\
\hline 284.09 & 3 & 20 & 28.62 & 28.75 \\
\hline 200 & 1.32 & 20 & 43.42 & 43.93 \\
\hline 200 & 4.68 & 20 & 42.60 & 42.08 \\
\hline 200 & 3 & 11.59 & 36.57 & 36.49 \\
\hline 200 & 3 & 28.41 & 53.37 & 53.43 \\
\hline 200 & 3 & 20 & 58.10 & 57.92 \\
\hline 200 & 3 & 20 & 57.92 & 57.92 \\
\hline 200 & 3 & 20 & 57.01 & 57.92 \\
\hline 200 & 3 & 20 & 58.40 & 57.92 \\
\hline 200 & 3 & 20 & 58.20 & 57.92 \\
\hline 200 & 3 & 20 & 57.89 & 57.92 \\
\hline
\end{tabular}

The coefficients of the regression model (Eq. 3) calculated are listed in Table 3, in which they contain three linear, three quadratic, three interaction terms and one block term. The effects of all three parameters, i.e. sugar, urea and inoculum and their interactions with each other, on ethanol concentration were found to be significant $(\mathrm{P}$ value $(\mathrm{Prob}>\mathrm{F}) \leq 0.05)$, indicating the model terms are significant).

The corresponding analysis of variance (ANOVA) was also carried out to check the best fit of the model. The $\mathrm{F}$ value for the best fit of the model was 1325.71 . The $F$ value for lack of fit test was 0.69 means lack of fit of the model was not significant, which was desirable. The coefficient of determination $\left(\mathrm{R}^{2}\right)$ was 0.9993, which implied that $99.93 \%$ of the sample variation in the ethanol yield is attributed to the independent variables. The $\mathrm{R}^{2}$ value also indicated that only $0.1 \%$ of the variation could not be explained by the model. The value of $\mathrm{R}$ is 0.9986 .

The parity plot showed a satisfactory correlation between experimental values and predictive values (Fig 1), wherein, the points cluster around the diagonal line which indicates the good fit of the model, since the deviation between the experimental and predictive values was low.

Optimum level for sugar, urea and inoculum concentration could be predicted using the equation model. Fig 4-6 represent the iso-response contour and surface plots for the optimization of fermentation conditions of ethanol production.

An increase in the sugar and urea concentration up to an optimum point increased the ethanol production to a maximum level; however, a further increase in the concentration reversed the trend (Fig 2). The optimum sugar and urea concentration for maximum ethanol production lies near the center point. The interaction effect of the inoculums and sugar concentration on the ethanol production clearly indicates a proper combination for production of ethanol (Fig 3). An increase in the inoculum and sugar concentration increased the ethanol production gradually, but at a higher inoculums and sugar concentration, the trend was reversed. A similar effect on the response was observed for the urea at any level of inoculums concentration. An increase in the urea and inoculums concentration up to an optimum point increased the ethanol production to maximum level, but a further increase in the urea and inoculum concentration decreased the ethanol production (Fig 4).

Therefore, the optimum condition was observed near the central value of sugar, urea and inoculum. The predicted optimum condition for maximum ethanol concentration were $206.01 \mathrm{~g} \mathrm{~L}^{-1}$ sugar, $3.16 \mathrm{~g} \mathrm{~L}^{-1}$ urea, and $23.05 \% \mathrm{v} \mathrm{v}^{-1}$ inoculum concentrations. With these optimized parameters, the maximum ethanol concentration obtained was $58.97 \mathrm{~g} \mathrm{~L}^{-1}$. 


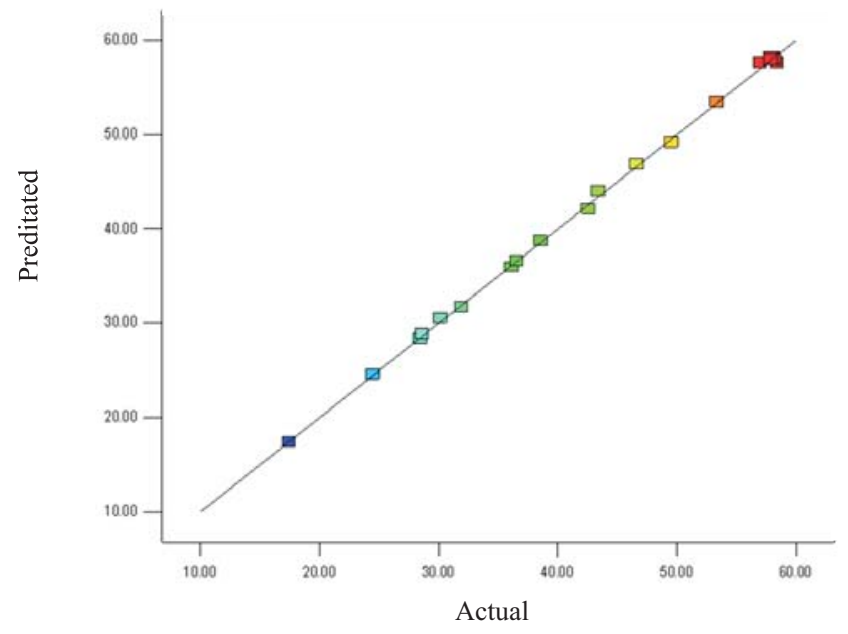

Fig 1 Parity plot showing the distribution of experimental vs. predicted values of ethanol yield.

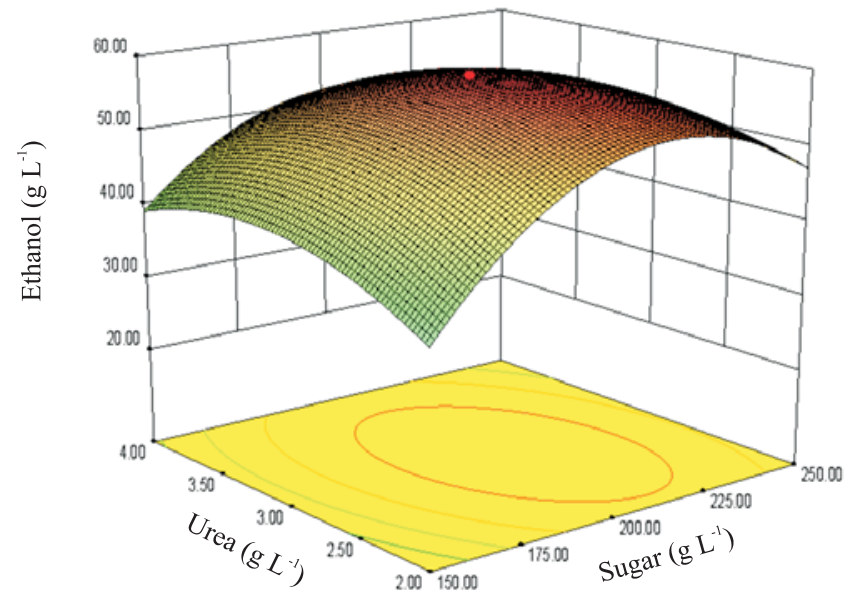

Fig 2 Response surface and contour plot of sugar vs. urea concentration on ethanol production (inoculums was kept constant at $20 \% \mathrm{v} / \mathrm{v} /$ ).

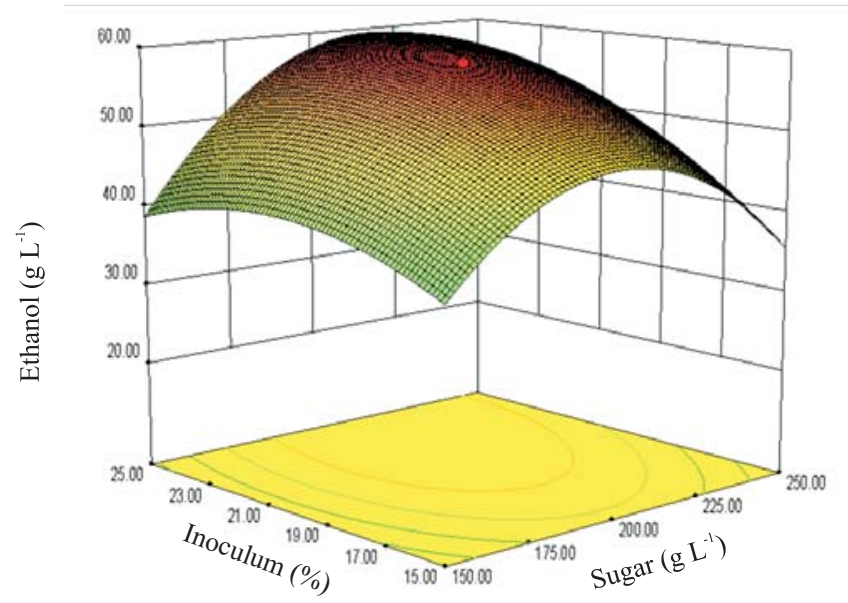

Fig 3 Response surface and contour plot of inoculums vs. sugar concentration on ethanol production (urea was kept constant at $\left.3 \mathrm{gL}^{1}\right)$.

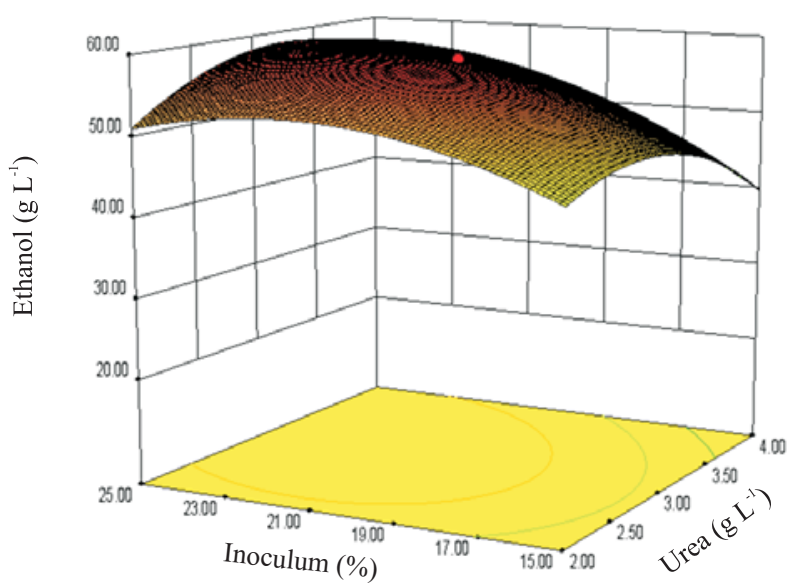

Fig 4 Response surface and contour plot of urea vs. inoculums on ethanol production (sugar concentration was kept constant at $200 \mathrm{~g} \mathrm{~L}^{-1}$ ).

\section{DISCUSSION}

The experimental and predicted ethanol production at optimum fermentation conditions were also determined (Table 5). The experimental maximum ethanol concentration of $59.77 \mathrm{~g} \mathrm{~L}^{-1}$ was obtained at optimum condition. A high similarity was observed between the predicted and experimental results, which reflected the accuracy and applicability of RSM to optimize the process for ethanol production. This result was nearly equal with the data of optimization ethanol production from the others sucrose based material e.g. sucrose, cane juice and molasses (Gunasekaran et al. 1986; Lee and Huang 1995; Cazetta et al. 2007), because the sucrose content of sugar syrup from palmyra sap was up to $92 \%$ of total sugar (Davis and Johnson 1987; Barh and Mazumdar 2008).

The ethanol yield calculated from the experimental data was listed in Table 6. The ethanol yield at optimum condition was $0.3039 \mathrm{~g} \mathrm{~g}^{-1}$. This obtained result was low because the percent yield of theoretical from this experiment was $59.5 \%$ whereas the capability of

Table 5 The of experimental and predicted ethanol yields at optimum condition.

\begin{tabular}{lccc}
\hline \multirow{2}{*}{ Variables } & Optimum & \multicolumn{2}{c}{$\begin{array}{c}\text { Optimum Ethanol Yield } \\
\left(\mathrm{g} \mathrm{L}^{-1}\right)\end{array}$} \\
\cline { 3 - 4 } & Value & Experimental & Predicted \\
\hline Sugar $\left(\mathrm{g} \mathrm{L}^{-1}\right)$ & 206.01 & & \\
Urea $\left(\mathrm{g} \mathrm{L}^{-1}\right)$ & 3.16 & 58.97 & 59.77 \\
Inoculums $\left(\% \mathrm{v} \mathrm{v}^{-1}\right)$ & 23.05 & & \\
& & & \\
\hline
\end{tabular}

\begin{tabular}{lc} 
Table 6 Ethanol yields & \\
\hline Paramaters & Value \\
\hline Ethanol yield, $\mathrm{Y}_{\mathrm{p} / \mathrm{s}}(\mathrm{g} / \mathrm{g})$ & 0.3039 \\
Ethanol yield, $(\%$ of theoretical $)$ & 59.5 \\
\hline
\end{tabular}


theoretical yield of Zymomonas mobilis should be $97 \%$. When Z. mobilis grows in sucrose, it converts sucrose into glucose and fructose using up to three sucrose-splitting enzymes and produce ethanol, levan and sorbitol (Sprenger 1996). Ethanol production by Z. mobilis using sucrose as carbon source is substantially reduced as a result of the levan and sorbitol formation (Lee and Huang 1995). Levan is produced by Z. mobilis only when the growth medium contains sucrose, but not when the medium contains a mixture of glucose and fructose (Dawes et al. 1996). To solve the problem, invertase can be added to the medium to hydrolyze sucrose. Lee and Huang (1995) reported that when sucrose was previously hydrolyzed by invertase, the level of levansucrase secretion will be lower and the formation of the total levan and sorbitol will decrease, hence increasing the ethanol production.

In other hand, Jayaseelan and Seevaratnam (1986) and Ratnam et al. (2005) reported the ethanol production from palmyra sap and jaggery using Saccharomyces cerevisiae. Compared with the previous report, it showed that Saccharomyces cerevisiae could produce higher ethanol on palmyra sugar than Zymomonas mobilis.

Optimization using RSM with Cental Composite Design method enables to find the importance factors at different levels. A high similarity was observed between the predicted and experimental results, reflecting the accuracy and applicability of RSM to optimize ethanol production. The results of this study clearly indicated that RSM is an effective method for maximum production of ethanol from palmyra sap using Zymomonas mobilis. The addition of invertase or coupling with the other invertase-producing microorganisms seemed to increase the yield of ethanol production from palmyra sap by Zymomonas mobilis.

\section{ACKNOWLEDGEMENTS}

The authors thank ASENDO (Indonesian Associations Spirits and Ethanol) for the financial support of the research and Agroindustrial Biotechnology Double Degree Master Program of Brawijaya University for the helpful guidance and the chemical analysis reagents.

\section{REFERENCES}

Ambati P, Ayyanna C. 2001. Optimizing medium constituents and fermentation conditions for citric acid production from palmyra jaggery using response surface method. World J Microbiol Biotechnol. 17(4):331-335. doi: 10.1023/A:1016613322396.

Bai FW, Anderson WA, Moo-Young M. 2008. Ethanol fermentation technologies from sugar and starch feedstock. Biotechnol Adv. 26(1):89-105. doi:10.1016/j.biotechadv.2007.09.002.
Bandaru VVR, Somalanka SR, Mendu DR, Madicherla NR, Chityala A. 2006. Optimization of fermentation conditions for the production of ethanol from sago starch by co-immobilized amyloglucosidase and cells of Zymomonas mobilis using response surface methodology. Enzyme Microb Technol. 38(1-2):209-214.

Barh D, Mazumdar BC. 2008. Comparative nutritive values of palm saps before and after their partial fermentation and effective use of wild date (Phoenix sylvestris Roxb.) sap in treatment of anemia. Res J Medicine Med Sci. 3(2): 173-176.

Box GEP, Hunter JS, Hunter WG. 2005. Statistic for experimenters: design, innovation and discovery. New Jersey: John Willey \& Sons.

Cazetta ML, Celligoi MAPC, Buzato JB, Scarmino IS. 2007. Fermentation of molasses by Zymomonas mobilis: Effects of temperature and sugar concentration on etanol production. Bioresource Technol. 98(15):2824-2828. doi:10.1016/j.biortech.2006.08.026.

Davis TA, Johnson DV. 1987. Current utilization and further development of the palmyra palm (Borassus flabellifer L., Arecaceae) in Tamil Nadu State, India. Econ Bot. 41:47-266.

Dawes EA, Ribbons DW, Rees DA. 1996. Sucrose utilization by Zymomonas mobilis: formation of a levan. Biochem J. 98(3):804-812.

Elisson A, Hofmeyr JHS, Pedler S, Hahn-Hagerdal B. 2001. The xylose reductase/xylitol dehydrogenase/xylulokinase ratio affects product formation in recombinant xylose-utilizing Saccharomyces cerevisiae. Enzyme Microb Technol. 29(4-5):288-297. doi:10.1016/S01410229(01)00386-6.

Gunasekaran P, Karunakaran T, Kasthuribai M. 1986. Fermentation pattern of Zymomonas mobilis strains on different substrates a comparative study. JBiosci.10(2):181-186.

Gunasekaran P, Raj KC. 1999. Ethanol fermentation technology Zymomonas mobilis. Curr Sci. 77(1): 56-68.

Jamai L, Ettayebi K, El Yamani J, Ettayebi M. 2007. Production of ethanol from starch by free and immobilized Candida tropicalis in the presence of -amylase. Bioresource Technol. 98(14):2765-2770. doi:10.1016/j.biortech.2006.09.057.

Jayaseelan K, Seevaratnam S. 1986. Ethanol and biomass from palmyra palm sap. Biotechnol Lett. 8(5):357-360. doi: 10.1007/BF01040866.

Jeffries TW. 2005. Ethanol fermentation on the move. Nat Biotechnol. 23(1):40-41. doi:10.1038/nbt0105-40.

Lee EC, Huang CT, 1995. Enhancement of ethanol production from sucrose by Zymomonas mobilis by the addition of immobilized invertase. Enzyme Microb Tech. 17(1):79-84. doi:10.1016/01410229(94)00042-P.

Lee EC, Huang CT, 2000. Modeling of ethanol fermentation using Zymomonas mobilis ATCC 10988 grown on the media containing glucose and fructose. Biochem Eng J. 4(3): 217-227. doi:10.1016/S1369-703X(99)00051-0.

Limtong S, Sringiew C, Yongmanitchai W. 2007. Production of fuel ethanol at high temperature from sugar cane juice by a newly isolated Kluyveromyces marxianus. Bioresource Technol. 98(17):2824-2828. doi:10.1016/j.biortech.2006.10.044.

Morton JF. 1988. Notes on Distribution, Propagation, and Products of Borassus Palms (Arecaceae). Econ Bot. 42:420-441.

Quintero JA, Montoya MI, Sa'nchez OJ, Giraldoc OH, Cardona CA. 2007. Fuel ethanol production from sugarcane and corn: comparative analysis for a Colombian case. Energy doi:10.1016/j.energy.2007. 10.001 .

Ratnam, BVV. 2001 Studies on physico-chemical and nutritional parametars for the production of ethanol from palmyra jaggery by submerged fermentation using Saccharomyces cerevisiae. [ $\mathrm{PhD}$ thesis]. Visakhapatnam, India: Andhra University

Ratnam, BVV, Rao NM, Rao DM, Rao SS, Ayyanna C. 2003. Optimization of fermentation conditions for the production of ethanol from sago starch using response methodology. World J Microbiol Biotechnol 19: 523-526

Ratnam BVV, Rao SS, Rao DM, Rao NM, Ayyanna C. 2005. Optimization of medium constituents and fermentation conditions for the production 
of ethanol from palmyra jaggery using response surface methodology. World J Microbiol Biotechnol. 21(4):399-404. doi: 10.1007/s11274004-2461-4.

Ristiarini S, Kuswardani I, Adikaryo MIL, Wahyuni M. 2001. [Succession pattern of indegenous microflora in nira siwalan fermentation and its usage in fermented drink] [in Indonesian]. Biota 4:1-8.

Rogers PL, Lee KJ, Skotinich ML, Tribe DE, 1982. Ethanol production by Zymomonas mobilis. Adv Biochem Eng. 23:2784. doi: 10.1007/3540116982 2 .

Rogers P, Joachimsthal E, Haggett K, 1997. Ethanol from lignocellulosics: potencial for Zymomonas-based process. Aust Biotechnol. 7(5):304309.

Sarulli N. 2009. Citric acid plant of Borassus flabellifer by submerged fermentation using Aspergillus niger [thesis]. Surabaya (ID): Institut Teknologi Sepuluh November.
Seo JS, Chong H, Park HS, Yoon KO, Jung C, Kim JJ, Hong JH, Kim H, Kim JH, Kil JI, Park CJ, Oh HM, Lee JS, Jin SJ, Um HW, Lee HJ, Oh SJ, Kim JY, Kang HL, Lee SY, Lee KJ, Kang HS. 2005. The genome sequence of the ethanologenic bacterium Zymomonas mobilis ZM4. Nat Biotechnol. 23(1):63-68. doi: 10.1038/nbt1045.

Sprenger GA. 1996. Carbohydrate metabolism in Zymomonas mobilis: a catabolic highway with some scenic routes. FEMS Microbiol Lett. 145(3):301 307. doi: 10.1111/j.1574-6968.1996. tb08593.x.

Sunitha I, Rao, SMV, Ayyanna C. 1998. Optimization of medium constituents and fermentation conditions for the production of $\mathrm{L}$ glutamic acid by the coimmobilized whole cells of Micrococus glutanicus and Pseudomonas reptilivora. Bioproc Eng. 18(5):353-359. doi: 10.1007/PL00008995.

Taherzadeh MK. Karimi. 2007. Acid-based hydrolysis process for ethanol from lignosellulosic material: a review. BioResource 2(3):472-449. 